\title{
2,3-Dimethoxy-2'-hydroxychalcone ameliorates TNF- $\alpha$-induced ICAM-1 expression and subsequent monocyte adhesiveness via NF-kappaB inhibition and HO-1 induction in HaCaT cells
}

\author{
Hyejin Kim ${ }^{1}$, Gi Soo Youn ${ }^{1}$, Soo Yeon An ${ }^{1}$, Hyeok Yil Kwon ${ }^{2}$, Soo Young Choi ${ }^{1}$ E Jinseu Park ${ }^{1, *}$ \\ ${ }^{1}$ Department of Biomedical Science and Research Institute for Bioscience \& Biotechnology, Hallym University, Chuncheon 24252, \\ ${ }^{2}$ Department of Physiology, College of Medicine, Hallym University, Chuncheon 24252, Korea
}

\begin{abstract}
Up-regulation of adhesion molecules plays an important role in the infiltration of leukocytes into the skin during the development of various inflammatory skin diseases, such as atopic dermatitis. In this study, we investigated the modulatory effects of 2,3-dimethoxy-2'-hydroxychalcone (DMHC) on tumor necrosis factor (TNF)- $\alpha$-induced intercellular adhesion molecule-1 (ICAM-1) expression and monocyte adhesiveness, as well as the molecular mechanisms underlying its action in the HaCaT human keratinocyte cell line. Pre-treating HaCaT cells with DMHC significantly suppressed TNF- $\alpha$-induced ICAM-1 expression and subsequent monocyte adhesiveness. DMHC inhibited TNF- $\alpha$-induced activation of NF- $\kappa \mathrm{B}$. In addition, DMHC induced HO-1 expression as well as NRF2 activation. Furthermore, HO-1 knockdown using siRNA reversed the inhibitory effect of DMHC on TNF- $\alpha$-induced ICAM-1 expression and adhesion of monocytes to keratinocytes. These results suggest that DMHC may inhibit TNF- $\alpha$-induced ICAM-1 expression and adhesion of monocytes to keratinocytes by suppressing the signaling cascades leading to NF- $\mathrm{KB}$ activation and inducing HO-1 expression in keratinocytes. [BMB Reports 2016; 49(1): 57-62]
\end{abstract}

\section{INTRODUCTION}

Infiltration of leukocytes into the skin is a characteristic feature of the inflammatory immune response involved in the development of various skin diseases such as atopic dermatitis (AD) (1). Upregulation of adhesion molecules, such as intercellular adhesion molecule-1 (ICAM-1), may accelerate infiltration of leukocytes into the inflamed skin area $(2,3)$. Epidermal keratinocytes, a major skin cell type, express ICAM- 1 in response to

${ }^{*}$ Corresponding author. Tel: +82-33-248-2116; Fax: +82-33-2563420; E-mail: jinpark@hallym.ac.kr

http://dx.doi.org/10.5483/BMBRep.2016.49.1.141

Received 6 July 2015, Revised 21 July 2015, Accepted 12 August 2015

Keywords: Adhesion, HO-1, Keratinocyte, NF-kB, TNF- $\alpha$ inflammatory cytokines, such as tumor necrosis factor alpha (TNF- $\alpha$ ) and interferon-gamma (4). Increased levels of ICAM-1 expression are observed in keratinocytes of inflamed lesions in patients with $A D$ and psoriasis $(5,6)$, suggesting that upregulation of ICAM-1 reflects the progression of inflammatory skin diseases (7). As ICAM-1 is critical for interactions between keratinocytes and leukocytes during skin inflammation, modulating ICAM-1 expression provides a rationale for developing therapeutic agents against various inflammatory skin diseases.

Nuclear factor-kappaB (NF- $\kappa \mathrm{B})$ is a major transcriptional factor mediating ICAM-1 expression (8). Stimulating keratinocytes with TNF- $\alpha$ activates the I $\kappa B$-kinase (IKK) complex, consisting of two kinase subunits (IKK $\alpha$ and IKK $\beta$ ) and a regulatory subunit IKK $\gamma /$ NEMO. The activated IKK complex phosphorylates $I \kappa B \alpha$, resulting in its ubiquitination and subsequent proteasomal degradation. NF- $\kappa B$ moves from the cytosol to the nucleus, where it induces transcription of the ICAM-1 gene (9).

A growing body of evidences suggests that many pharmacological compounds exert their anti-inflammatory activities by inducing heme oxygenase- 1 (HO-1) expression in inflammatory disease models (10). HO-1 catalyzes the degradation of heme, leading to the generation of ferrous iron, carbon monoxide, and biliverdin. These by-products mediate the beneficial effects of HO-1 expression in a number of pathological conditions (11). Previous studies have shown that HO-1 expression exerts immune-modulatory effects against inflammatory skin diseases, such as AD (12-14).

2,3-Dimethoxy-2'-hydroxychalcone (DMHC) is a derivative of $2^{\prime}$-hydroxychalcone in the flavonoid family (15). $2^{\prime}$-Hydroxychalcone derivatives exert potent anti-inflammatory activity in in vitro and in vivo models. 2'-Hydroxychalcone derivatives inhibit polymixin B-induced hind-paw edema in mice (16), and 2'-hydroxychalcone suppresses TNF- $\alpha$ - and lipopolysaccharide (LPS)-induced ICAM-1, VCAM-1, and E-selectin expression by blocking activation of NF- $\kappa B$ in human umbilical vein endothelial cells (17). 2'-Hydroxychalcone derivatives inhibit nitric oxide (NO) and TNF- $\alpha$ production in LPS-stimulated RAW 264.7 macrophages by inhibiting NF- $\mathrm{KB}$ and AP-1 activation (18). In contrast, $2^{\prime}$-hydroxychalcone inhibits LPS-induced $\mathrm{NO}$ and TNF- $\alpha$ production by inducing HO-1, without affect-

ISSN: 1976-670X (electronic edition)

Copyright (C) 2016 by the The Korean Society for Biochemistry and Molecular Biology

(c) This is an open-access article distributed under the terms of the Creative Commons Attribution Non-Commercial License (http://creativecommons.org/licenses/by-nc/4.0) which permits unrestricted non-commercial use, distribution, and reproduction in any medium, provided the original work is properly cited. 
ing activation of NF- $\kappa B$ in RAW 264.7 macrophages (19), suggesting that 2 '-hydroxychalcone exerts anti-inflammatory effects via multiple mechanisms. However, very little is known about the protective effects of $2^{\prime}$-hydroxychalcone and its mechanism of action in keratinocytes.

In this study, we examined the inhibitory effect of DMHC on TNF- $\alpha$-induced ICAM-1 expression and the molecular mechanism responsible for these activities in the $\mathrm{HaCaT}$ human keratinocyte cell line. Our results suggest that DMHC may exert anti-inflammatory effects by inhibiting NF-kB activation and inducing $\mathrm{HO}-1$ expression in keratinocytes.

\section{RESULTS}

Effect of DMHC on TNF- $\alpha$-induced ICAM-1 expression and subsequent monocyte adhesion in $\mathrm{HaCaT}$ cells

Cell viability was examined with the MTT assay to exclude the possibility that DMHC cytotoxicity (Fig. 1A) might contribute to its anti-inflammatory effects. As shown in Fig. 1B, DMHC had no significant cytotoxic effect on HaCaT cells in the absence or presence of TNF- $\alpha$ up to a concentration of $20 \mu \mathrm{M}$. We next examined the effect of DMHC on TNF- $\alpha$-induced ICAM-1 expression in HaCaT cells. DMHC significantly inhibited TNF- $\alpha$-induced ICAM-1 expression at the mRNA and protein levels in a dose-dependent manner (Fig. 1C). We further investigated the effect of DMHC on TNF- $\alpha$-induced monocyte adhesion to HaCaT cells. As shown in Fig. 1D, DMHC significantly suppressed TNF- $\alpha$-induced monocyte adhesion to HaCaT cells in a dose-dependent manner (Fig. 1D).

\section{Effect of DMHC on TNF- $\alpha$-induced NF- $\kappa B$ activation in HaCaT cells}

NF- $\kappa B$ signaling pathway is activated upon stimulation with TNF- $\alpha$ to induce ICAM-1 expression (9). We investigated the effect of DMHC on signaling cascades leading to NF- $\mathrm{KB}$ activation in TNF- $\alpha$-stimulated HaCaT cells. We examined the effect of $\mathrm{DMHC}$ on TNF- $\alpha$-induced IKK $\alpha / \beta$ activation using antibodies against total and phosphorylated IKK $\alpha / \beta$. DMHC significantly inhibited TNF- $\alpha$-induced IKK $\alpha / \beta$ phosphorylation (Fig. 2A). DMHC also suppressed TNF- $\alpha$-induced degradation of $I \kappa B \alpha$ and phosphorylation of NF- $\kappa B$ p65 in a dose-dependent manner (Fig. 2B). We next examined the effect of DMHC on TNF- $\alpha$-induced NF- $\kappa B$ p65 DNA binding activity using an electrophoretic mobility shift assay (EMSA). DMHC significantly reduced TNF- $\alpha$-induced p65 DNA binding activity in a dose-dependent manner in $\mathrm{HaCaT}$ cells (Fig. 2C). We further evaluated the effect of DMHC on NF- $\mathrm{BB}$ promoter activity in TNF- $\alpha$-stimulated HaCaT cells. As shown in Fig. 2D, DMHC suppressed NF- $\kappa \mathrm{B}$ promoter activity in a dose-dependent manner. These results suggest that DMHC exerts its anti-inflammatory activity by inhibiting the signaling cascades leading to NF- $\kappa B$ activation.

\section{DMHC induces HO-1 expression in HaCaT cells}

As many chalcone derivatives exert their biological activities by inducing HO-1 expression (15), we next examined whether DMHC induced HO-1 expression in HaCaT cells. Cells were treated with various doses of DMHC $(5-15 \mu \mathrm{M})$ for the indicated times, and HO-1 expression was analyzed by RT-PCR and Western blotting. As shown in Fig. $3 \mathrm{~A}$ and $\mathrm{B}$, DMHC significantly induced HO-1 mRNA and protein expression in
A

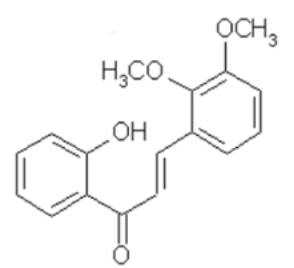

2,3-dimethoxy-2'-hydroxychalcone (DMHC)

C

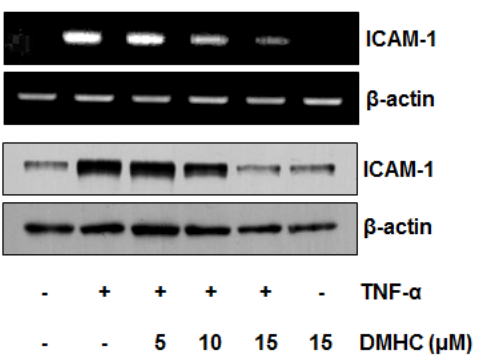

B

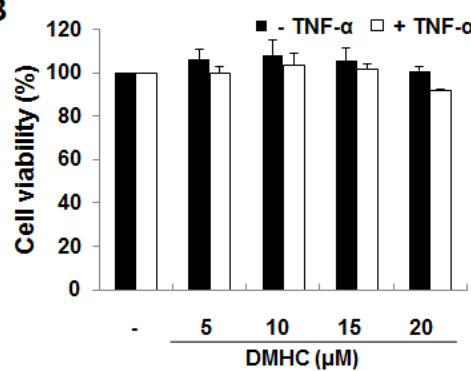

D

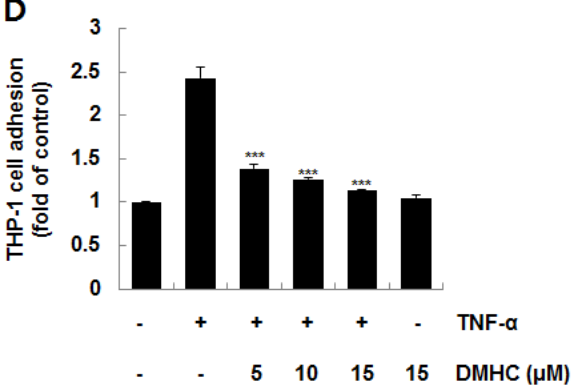

Fig. 1. DMHC inhibits TNF- $\alpha$-induced ICAM-1 expression and subsequent monocyte adhesion in HaCaT cells. (A) Chemical structure of DMHC. (B) Cytotoxic effects of DMHC in HaCaT cells. The cells were incubated with the indicated doses of $\mathrm{DMHC}$ in the absence or presence of TNF- $\alpha$ (10 $\mathrm{ng} / \mathrm{ml}$ ) for $24 \mathrm{~h}$ and cell viability was determined with the MTT assay. (C) Effects of DMHC on TNF- $\alpha$-induced expression of the ICAM-1 gene in $\mathrm{HaCaT}$ cells. Cells were pretreated with the indicated doses of DMHC for $3 \mathrm{~h}$, and then exposed to TNF- $\alpha(10 \mathrm{ng} / \mathrm{ml})$ for $1 \mathrm{~h}$ (for RNA) or $12 \mathrm{~h}$ (for protein). Total RNA and protein were analyzed by RT-PCR (upper panel) and Western blot (lower panel), respectively. (D) Effects of DMHC on monocyte adhesiveness in TNF- $\alpha$-stimulated $\mathrm{HaCaT}$ cells. Cells were pretreated with various doses of $\mathrm{DMHC}$ for $3 \mathrm{~h}$, and then exposed to TNF- $\alpha$ (10 $\mathrm{ng} / \mathrm{ml}$ ) for $12 \mathrm{~h}$. Calcein-AM-labeled THP-1 monocytes were added to the HaCaT cells and incubated for $1 \mathrm{~h}$. Calcein-AM fluorescence intensity was quantitated using an ELISA plate reader. Data are presented as the means + SD of three experiments. $* * * \mathrm{P}<0.001$ compared to TNF- $\alpha$ alone. 
A

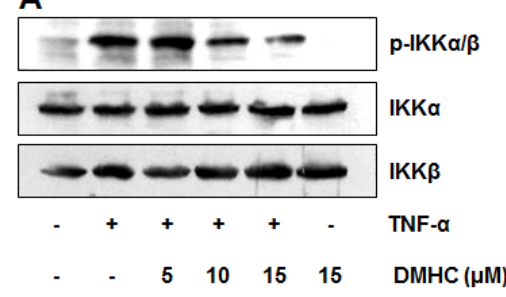

B

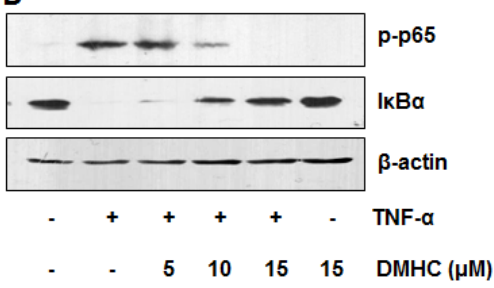

C

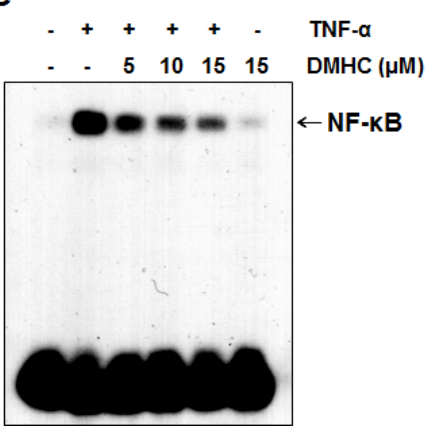

A

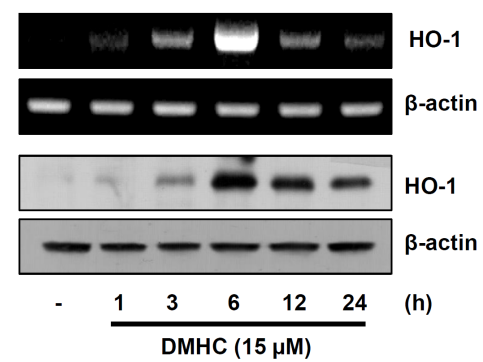

C

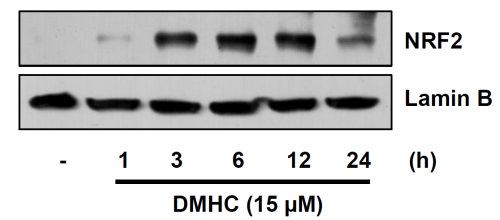

D

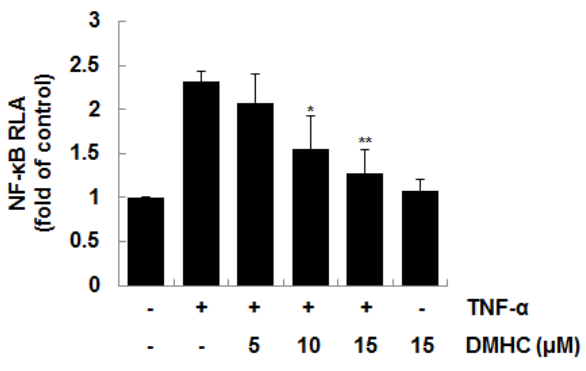

B

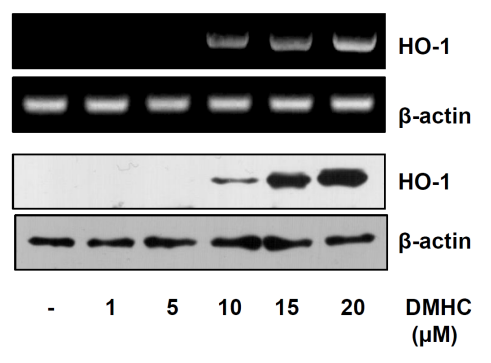

D

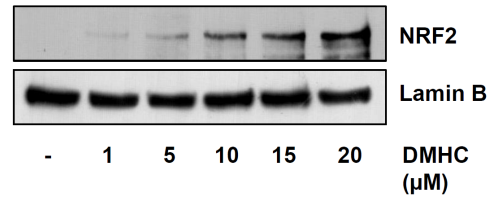

Fig. 2. DMHC suppresses the TNF- $\alpha$-induced NF- $\kappa B$ signaling cascade in $\mathrm{HaCaT}$ cells. Cells were pretreated with various doses of $\mathrm{DMHC}$ for $3 \mathrm{~h}$ and then exposed to TNF- $\alpha(10 \mathrm{ng} / \mathrm{ml})$ for 15 min. (A) Whole cell lysates were analyzed for IKK $\alpha / \beta$ activation by Western blotting using phospho-specific antibodies. (B) Cell lysates were analyzed for the levels of total $\mathrm{I}_{\kappa} \mathrm{B} \alpha$ and phosphorylated $\mathrm{p} 65$ by Western blot analysis. (C) Cells pretreated with DMHC for $3 \mathrm{~h}$ were exposed to TNF- $\alpha(10 \mathrm{ng} / \mathrm{ml})$ for $15 \mathrm{~min}$. Nuclear extracts were prepared and analyzed for p65 DNA-binding activity by EMSA. (D) DMHC decreased NF- $\kappa B$ promoter activity. HaCaT cells were transiently transfected with an NF- $\kappa \mathrm{B}$ promoter-luciferase construct and a $\beta$-galactosidase construct (pCMV-lacZ). The cells were pretreated with $\mathrm{DMHC}$ for $3 \mathrm{~h}$ at $48 \mathrm{~h}$ after transfection and then exposed to TNF- $\alpha$ for $24 \mathrm{~h}$. Cell extracts were prepared and analyzed for the luciferase activity assay using a luminometer. Luciferase activities are normalized to $\beta$-galactosidase activities and expressed as fold increases over the control. RLA, relative luciferase activity. Data are presented as means $\pm \mathrm{SD}$ of three experiments. $* \mathrm{P}<0.05$ and $* * \mathrm{P}<0.01$ compared to TNF- $\alpha$ alone.
Fig. 3. DMHC induces HO-1 expression and activates NRF2 in HaCaT cells. (A) Cells were treated with DMHC for the indicated periods. Total RNA and protein were analyzed by RT-PCR (upper panel) and Western blotting (bottom panel), respectively. (B) Cells were incubated with DMHC for $3 \mathrm{~h}$ (for RNA) or $12 \mathrm{~h}$ (for protein). Total RNA and protein were analyzed by RT-PCR (upper panel) and Western blotting (bottom panel), respectively. (C) Cells were treated with DMHC for the indicated periods. Cell nuclear extracts were analyzed for NRF2 level by Western blotting. (D) After incubating with various DMHC concentrations for $3 \mathrm{~h}$, nuclear extracts were prepared from the cells and were analyzed for NRF2 level by Western blotting. time- and dose-dependent manners. As nuclear factor (erythroidderived 2)-like 2 (NRF2) is a major transcriptional factor in the regulation of HO-1 expression (11), we examined NRF2 activation in $\mathrm{HaCaT}$ cells. Cells were treated with $\mathrm{DMHC}$, and the cell nuclear fraction was prepared and analyzed for translocation of NRF2 into the nucleus by Western blotting. As shown in Fig. 3C and D, DMHC strongly induced nuclear accumulation of NRF2 in time- and dose-dependent manners in $\mathrm{HaCaT}$ cells. These results suggest that DMHC is a potential inducer of HO-1 by activating NRF2 in HaCaT cells.
HO-1 mediates the inhibitory effect of DMHC on TNF- $\alpha$-induced ICAM-1 expression and monocyte adhesion in $\mathrm{HaCaT}$ cells

We used a siRNA knockdown strategy against HO-1 to examine the functional relevance of $\mathrm{HO}-1$ expression in the inhibitory effect of DMHC on TNF- $\alpha$-induced ICAM-1 expression. As shown in Fig. $4 \mathrm{~A}$ and $\mathrm{B}$, knockdown of HO-1 using siRNA significantly reversed the inhibitory effect of DMHC on TNF- $\alpha$-induced ICAM- 1 expression at the mRNA and pro- 
A

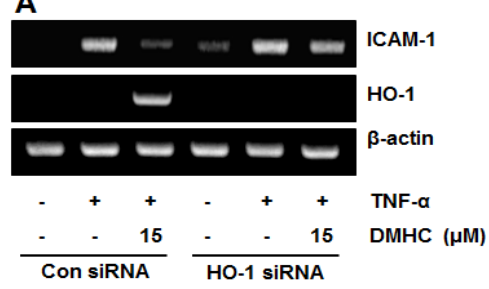

B

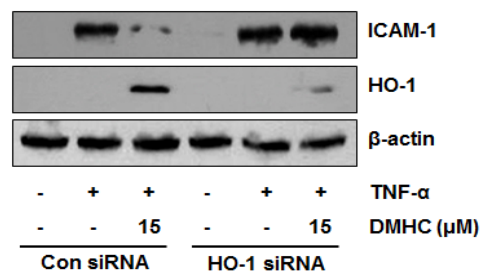

C
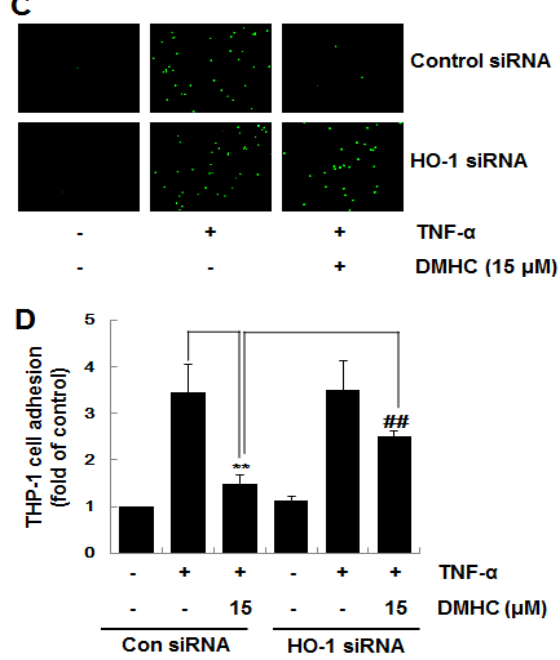

Fig. 4. HO-1 expression mediates the inhibitory effect of DMHC on TNF- $\alpha$-induced ICAM-1expression and monocyte adhesion in HaCaT cells. (A, B) The cells were transiently transfected with control or HO-1 siRNA to knockdown the HO-1 gene. After $48 \mathrm{~h}$ of transfection, the cells were pretreated with $\mathrm{DMHC}$ for $3 \mathrm{~h}$, and then stimulated with TNF- $\alpha$ for $1 \mathrm{~h}$ (for RNA) or $12 \mathrm{~h}$ (for protein). Total RNA and protein were analyzed by RT-PCR (A) and Western blotting $(B)$, respectively. (C, D) Cells transfected with control or HO-1 siRNA were incubated with DMHC for $3 \mathrm{~h}$, and then stimulated with TNF- $\alpha$ for $12 \mathrm{~h}$. HaCaT cells were co-cultured with calcein-AM-labeled THP-1 monocytes for $1 \mathrm{~h}$. (C) Microscopic images were obtained using a fluorescence microscope (original magnification, $\times 40$ ). (D) Calcein-AM fluorescence intensity was quantified using a fluorescence plate reader. Data are presented as means \pm SD of three independent experiments. ${ }^{* * P}<0.01$ compared to TNF- $\alpha$ alone, ${ }^{\# \#} \mathrm{P}<0.01$ compared to TNF- $\alpha$ and DMHC. tein levels. In addition, HO-1 knockdown significantly reversed the inhibitory effect of DMHC on TNF- $\alpha$-induced monocyte adhesion (Fig. 4C and D). These results support the notion that HO-1 expression is involved in mediating the suppressive effects of DMHC on TNF- $\alpha$-induced ICAM-1 expression and monocyte adhesion.

\section{DISCUSSION}

Infiltration of leukocytes into inflamed areas is a critical step in the development of inflammatory skin diseases. Various proinflammatory stimuli, such as TNF- $\alpha$, participate in upregulating adhesion molecules, such as ICAM-1, in keratinocytes, which play an important role in leukocyte infiltration into the skin (4). Therefore, modulating the expression of adhesion molecules is a good strategy to treat inflammatory skin diseases. In this study, we evaluated the anti-inflammatory effects of DMHC on keratinocytes. We showed that DMHC suppressed TNF- $\alpha$-induced ICAM-1 expression by inhibiting NF- $\mathrm{KB}$ activation and upregulating $\mathrm{HO}-1$ expression in keratinocytes.

Upon stimulation with TNF- $\alpha$, keratinocytes express adhesion molecules, such as ICAM-1, that facilitates infiltration of leukocytes into the inflamed skin area. Several studies have reported that increased ICAM-1 expression levels in keratinocytes are observed in inflamed lesions of patients with $\mathrm{AD}$ and psoriasis $(5,6)$. We performed experiments to examine the effect of DMHC on TNF- $\alpha$-induced ICAM- 1 expression in HaCaT cells. Pretreatment with DMHC significantly inhibited ICAM-1 expression at the mRNA and protein levels in TNF- $\alpha-$ stimulated HaCaT cells. In addition, DMHC significantly suppressed TNF- $\alpha$-induced monocyte adhesion to HaCaT cells. These results suggest that DMHC modulates against inflammatory responses.

$\mathrm{NF}-\kappa \mathrm{B}$ is the principle transcription factor mediating ex- pression of various pro-inflammatory genes including ICAM-1 (8). NF- $\mathrm{KB}$ is associated with $\mathrm{I} \mathrm{KB} \alpha$ in unstimulated cells and resides in the cytosol. Stimulating cells with TNF- $\alpha$ activates the IKK complex, consisting of two kinase subunits (IKK $\alpha$ and IKK $\beta$ ) and a regulatory subunit IKK $\gamma /$ NEMO. The activated IKK complex phosphorylates $I \kappa B \alpha$, which is, in turn, degraded by proteasomes. NF-kB moves to the nucleus, where it induces the transcription of pro-inflammatory genes. We performed experiments to evaluate the modulatory activity of $\mathrm{DMHC}$ on the signaling pathways leading to NF- $\kappa B$ activation in TNF- $\alpha$-stimulated HaCaT cells. DMHC significantly inhibited IKK phosphorylation, $1 \kappa \mathrm{B} \alpha$ degradation, and p65 phosphorylation in TNF- $\alpha$-stimulated HaCaT cells. In addition, DMHC decreased TNF- $\alpha$-induced p65 DNA-binding and NF- $\mathrm{BB}$ promoter activities (Fig. 2C and 2D). These results indicate that DMHC modulates the signaling cascades leading to NF- $\kappa B$ activation.

As various chalcone derivatives exert their anti-inflammatory activities by inducing $\mathrm{HO}-1$ expression in various inflammatory models $(15,19)$, we first performed an experiment to evaluate the ability of DMHC to induce HO-1 expression. DMHC induced $\mathrm{HO}-1$ expression at the mRNA and protein levels in time- and dose-dependent manners in $\mathrm{HaCaT}$ cells, indicating that $\mathrm{DMHC}$ is an inducer of HO-1 expression. NRF2 is a major transcriptional factor responsible for expression of the HO-1 gene (11). We observed that DMHC activated NRF2 by promoting translocation of NRF2 to the nucleus in time- and dose-dependent manners in $\mathrm{HaCaT}$ cells. HO-1 knockdown significantly reversed the inhibitory effect of DMHC on TNF- $\alpha$-induced ICAM-1 expression and subsequent monocyte adhesion to $\mathrm{HaCaT}$ cells, suggesting the involvement of $\mathrm{HO}-1$ expression in the anti-inflammatory effects of DMHC. A growing body of evidence suggests that $\mathrm{HO}-1$ expression is involved in the protective effects against inflammatory skin diseases (12-14). HO-1 expression exerts a modulatory effect on the keratinocyte in- 
flammatory response $(20,21)$. Ferrous iron, carbon monoxide, and bilirubin, generated from HO-1 activity, may contribute to the beneficial effect of HO-1 inducers (11). Activating NRF2 may affect the expression of a variety of antioxidant and detoxification genes. Because HO-1 expression partly contributed to the anti-inflammatory effects of DMHC in HaCaT cells, we cannot rule out possible involvement of antioxidant and detoxification genes other than HO-1 in this process. Taken together, these results indicate that DMHC-induced HO-1 expression contributes to the inhibitory effects of DMHC on TNF- $\alpha$-induced ICAM-1 expression and subsequent monocyte adhesion in keratinocytes.

In conclusion, we provide evidence that DMHC exerts its inhibitory effect on TNF- $\alpha$-induced ICAM-1 expression and subsequent monocyte adhesion to keratinocytes by blocking the signaling cascades leading to NF- $\mathrm{KB}$ activation. In addition, the anti-inflammatory activity of DMHC is mediated via HO-1 induction. These results provide molecular evidence that DMHC may have therapeutic potential against inflammatory skin diseases.

\section{MATERIALS AND METHODS}

\section{Cell culture and reagents}

Human immortalized keratinocyte cell line, HaCaT, and human THP-1 monocytes were maintained as described previously (20). Recombinant human TNF- $\alpha$ was purchased from R\&D Systems (Minneapolis, MN, USA). MTT was obtained from Duchefa (Haarlem, the Netherlands). Calcein acetoxymethyl ester (calcein-AM) was purchased from Molecular Probes (Eugene, OR, USA). Primary antibodies against ICAM-1, Nrf2, lamin B, $\beta$-actin (Santa Cruz Biotechnology, Santa Cruz, CA, USA), HO-1 (Enzo Life Sciences, Basel, Switzerland), IкB $\alpha$, and phospho-p65 (Cell Signaling Technology, Beverly, MA, USA) were obtained commercially. DMHC was purchased from Extrasynthese (Genay, France). A $25 \mathrm{mM}$ DMHC stock was prepared in ethanol, stored at $-20^{\circ} \mathrm{C}$, and diluted with DMEM for experiments.

\section{MTT assay}

Cell viability was evaluated using a MTT colorimetric assay as described previously (22).

\section{Western blot analysis}

Total proteins in cell extracts or nuclear extracts were measured using the Bradford protein assay (Bio-Rad, Hercules, CA, USA). The protein samples $(30-50 \mu \mathrm{g})$ were separated on a $10 \%$ sodium dodecyl sulfate-polyacrylamide gel and were transferred to a nitrocellulose membrane that was blocked with $10 \%$ dry milk in TBST $(137 \mathrm{mM} \mathrm{NaCl}, 20 \mathrm{mM}$ Tris- $\mathrm{HCl}$, $\mathrm{pH} 7.6,0.1 \%$ Tween 20) and incubated with the indicated antibodies. Immuno-reactive bands were visualized by an enhanced chemiluminescence detection kit (Millipore, Billerica, MA, USA) (21).

\section{RT-PCR analysis}

Total RNA from HaCaT cells was analyzed as described previously (20).

\section{Cell adhesion assay}

Monocyte adhesiveness to HaCaT cells was determined using a cell-cell adhesion assay described previously (22).

\section{EMSA}

HaCaT cells were treated with DMHC for $3 \mathrm{~h}$ and then exposed to TNF- $\alpha(10 \mathrm{ng} / \mathrm{ml})$ for $15 \mathrm{~min}$. Cell nuclear extracts were prepared and analyzed for NF- $\mathrm{\kappa B}$ binding activity using an EMSA as described previously $(23,24)$.

\section{Transfection}

Co-transfection of $\mathrm{HaCaT}$ cells with NF-кB-luc reporter plasmid (Stratagene, La Jolla, CA, USA) and a control (pCMV- $\beta$-galactosidase) plasmid was performed for the reporter assay as described previously (23). To perform the HO-1 siRNA knockdown experiments, $\mathrm{HaCaT}$ cells were transfected with control siRNA or HO-1 siRNA using Lipofectamine 3000. After a $48 \mathrm{~h}$ transfection, the cells were treated with DMHC for $3 \mathrm{~h}$ and then exposed to TNF- $\alpha(10 \mathrm{ng} / \mathrm{ml})$ for analysis of ICAM- 1 expression and monocyte adhesion.

\section{Statistical analysis}

Results are expressed as the means \pm standard errors from at least three independent experiments. The values were evaluated via one-way analysis of variance, followed by Duncan's multiple range test using GraphPad Prism 4.0 software (GraphPad Software, Inc., San Diego, CA, USA). Differences were considered significant at $\mathrm{P}<0.05$.

\section{ACKNOWLEDGEMENTS}

This work was supported by the Regional Research Universities Program/Medical \& Bio-material Research Center Grant, by the Priority Research Centers Program Grant (2009-0093812). This work was also supported by a Grant (HRF-G-2015-2) from Hallym University.

\section{REFERENCES}

1. Gröne A (2002) Keratinocytes and cytokines. Vet Immunol Immunopathol 88, 1-12

2. Dustin ML, Singer KH, Tuck DT and Springer TA (1988) Adhesion of T lymphoblasts to epidermal keratinocytes is regulated by interferon gamma and is mediated by intercellular adhesion molecule 1 (ICAM-1). J Exp Med 167, 1323-1340

3. Trefzer U, Brockhaus M, Loetscher $\mathrm{H}$ et al (1991) 55-kd tumor necrosis factor receptor is expressed by human keratinocytes and plays a pivotal role in regulation of human keratinocyte ICAM-1 expression, J Invest Dermatol 97, 911-916 
4. Albanesi C, Scarponi C, Giustizieri ML and Girolomoni G (2005) Keratinocytes in inflammatory skin diseases. Curr Drug Targets Inflamm Allergy 4, 329-334

5. Griffiths CE, Voorhees JJ and Nickoloff BJ (1989) Characterization of intercellular adhesion molecule-1 and HLA-DR expression in normal and inflamed skin: modulation by recombinant gamma interferon and tumor necrosis factor. J Am Acad Dermatol 20, 617-629

6. Matsunaga T, Katayama I, Yokozeki $\mathrm{H}$ and Nishioka $\mathrm{K}$ (1996) ICAM-1 expression on keratinocytes in mechanically-injured skin of a patient with atopic dermatitis. J Dermatol Sci 12, 219-226

7. Nickoloff BJ, Griffiths CE and Barker JN (1990) The role of adhesion molecules, chemotactic factors, and cytokines in inflammatory and neoplastic skin disease-1990 update. J Invest Dermatol 94, 151S-157S

8. Ali S and Mann DA (2004) Signal transduction via the NF- $\kappa B$ pathway: a targeted treatment modality for infection, inflammation and repair. Cell Biochem Funct 22, 67-79

9. Gloire G, Legrand-Poels S and Piette J (2006) NF-кB activation by reactive oxygen species: fifteen years later. Biochem Pharmacol 72, 1493-1505

10. Paine A, Eiz-Vesper B, Blasczyk R and Immenschuh S (2010) Signaling to heme oxygenase-1 and its anti-inflammatory therapeutic potential. Biochem Pharmacol 80, 1895-1903

11. Ryter SW, Alam J and Choi AM (2006) Heme oxygenase-1/carbon monoxide: from basic science to therapeutic applications. Physiol Rev 86, 583-650

12. Listopad J, Asadullah K, Sievers C et al (2007) Heme oxygenase-1 inhibits $\mathrm{T}$ cell-dependent skin inflammation and differentiation and function of antigen-presenting cells. Exp Dermatol 16, 661-670

13. Kirino M, Kirino $Y$, Takeno M et al (2008) Heme oxygenase 1 attenuates the development of atopic dermatitis-like lesions in mice: implications for human disease. J Allergy Clin Immunol 122, 290-297

14. Pae HO, Ha YA, Chai KY and Chung HT (2008) Heme oxygenase-1 attenuates contact hypersensitivity induced by 2,4-dinitrofluorobenzene in mice. Immunopharmacol Immunotoxicol 30, 207-216

15. Bukhari SN, Jantan I and Jasamai M (2013) Anti-inflamma- tory trends of 1, 3-diphenyl-2-propen-1-one derivatives. Mini Rev Med Chem 13, 87-94

16. Hsieh HK, Lee TH, Wang JP, Wang JJ and Lin CN (1998) Synthesis and anti-inflammatory effect of chalcones and related compounds. Pharm Res 15, 39-46

17. Madan B, Batra S and Ghosh B (2000) 2'-hydroxychalcone inhibits nuclear factor-kappaB and blocks tumor necrosis factor-alpha- and lipopolysaccharide-induced adhesion of neutrophils to human umbilical vein endothelial cells. Mol Pharmacol 58, 526-534

18. Ban HS, Suzuki K, Lim SS et al (2004) Inhibition of lipopolysaccharide-induced expression of inducible nitric oxide synthase and tumor necrosis factor-alpha by 2'-hydroxychalcone derivatives in RAW 264.7 cells. Biochem Pharmacol 67, 1549-1557

19. Abuarqoub H, Foresti R, Green CJ and Motterlini R (2006) Heme oxygenase- 1 mediates the anti-inflammatory actions of 2'-hydroxychalcone in RAW 264.7 murine macrophages. Am J Physiol Cell Physiol 290, C1092-C1099

20. Youn GS, Kwon DJ, Ju SM, Choi SY and Park J (2013) Curcumin ameliorates TNF- $\alpha$-induced ICAM- 1 expression and subsequent THP-1 adhesiveness via the induction of heme oxygenase- 1 in the HaCaT cells. BMB Rep 46, 410415

21. Kwon DJ, Bae YS, Ju SM, Goh AR, Choi SY and Park J (2011) Casuarinin suppresses TNF- $\alpha$-induced ICAM-1 expression via blockade of NF- $\kappa \mathrm{B}$ activation in $\mathrm{HaCaT}$ cells. Biochem Biophys Res Commun 409, 780-785

22. Seo WY, Ju SM, Song HY et al (2010) Celastrol suppresses IFN-gamma-induced ICAM-1 expression and subsequent monocyte adhesiveness via the induction of heme oxygenase -1 in the HaCaT cells. Biochem Biophys Res Commun 398, 140-145

23. Shin SY, Kim CG and Lee YH (2013) Egr-1 regulates the transcription of the BRCA1 gene by etoposide. BMB Rep 46, 92-96

24. Kwon DJ, Bae YS, Ju SM, Youn GS, Choi SY and Park J (2014) Salicortin suppresses lipopolysaccharide-stimulated inflammatory responses via blockade of NF-KB and JNK activation in RAW 264.7 macrophages. BMB Rep 47, 318-323 